DOI 10.37882/2223-2982.2020.04-2.33

\title{
ТРАДИЦИИ ГУМАНИЗМА И НРАВСТВЕННЫЕ ИДЕАЛЫ СОВРЕМЕННЫХ СТУДЕНТОВ МЕДИЦИНСКИХ СПЕЦИАЛЬНОСТЕЙ
}

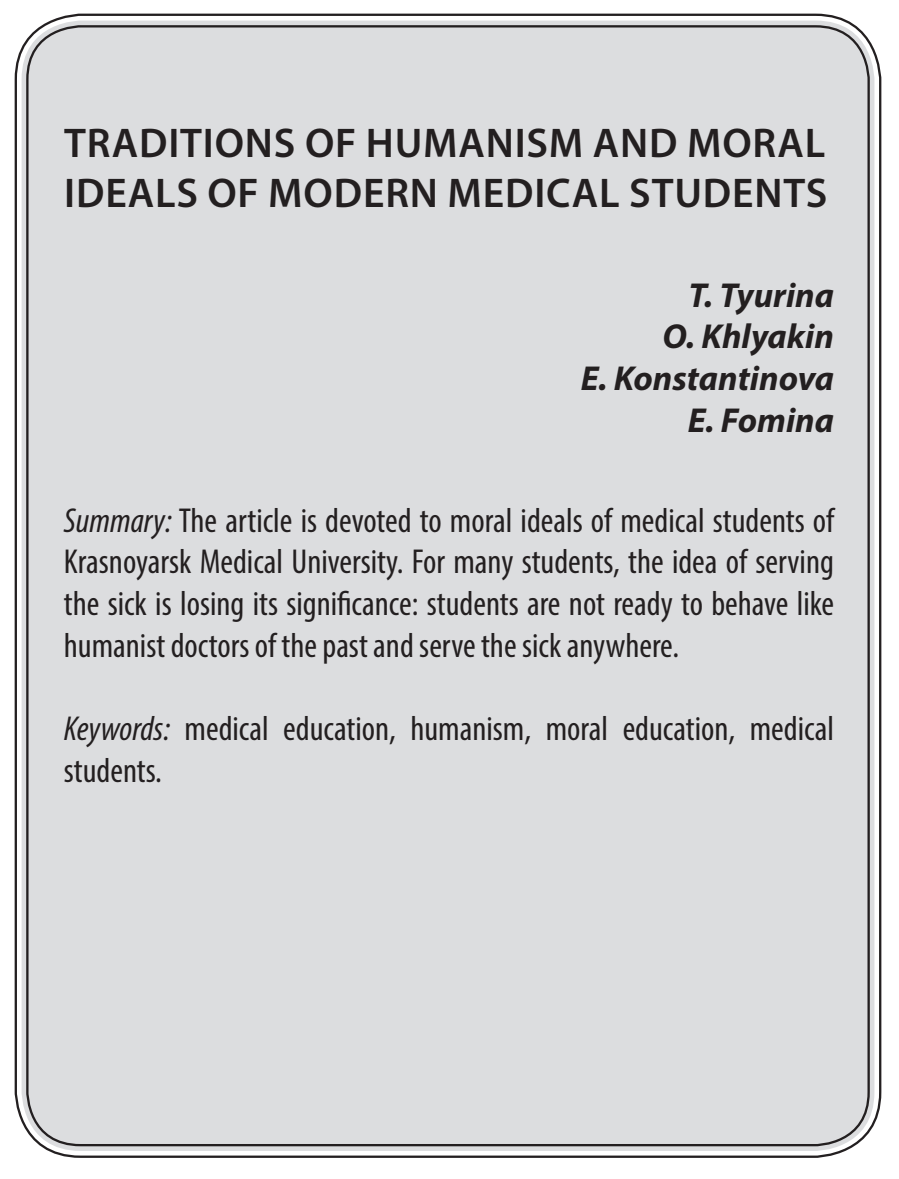

$\mathrm{B}$ настоящее время актуальной становится проблема нравственного воспитания студентов медицинских специальностей. Опубликовано большое количество статей, посвященных как отдельным проблемам безнравственного поведения студентов [ см.напр. 1] , так и проблемам воспитания добродетелей в целом [см. напр.3,4]

Эта проблема связана с общим мировоззренческим кризисом молодежи в стране. А.Н. Агеев писал о том, что у молодежи размыты представления о доброте, милосердии, великодушии, справедливости, гражданственности [1 c.47]. Другое дело что хотелось бы уточнить что именно было размыто. Нашу точку зрения мы бы хотели обосновать результатами опроса, проведенного в мае 2019 г. среди студентов первого курса лечебного факультета Красноярского государственного медицинского университета.

Целью статьи является анализ нравственных идеа-
Тюрина Татьяна Валерьевна,

К.филол.н., дочент, Красноярский государственный медицинский университет имени профессора В.Ф. Войно-Ясенечкого tyurina12@mail.ru

Хлякин Олег Сергеевич, к.ф.н., дочент, Красноярский государственный медицинский университет имени профессора В.Ф. Войно-Ясенецкого khlyakin@yandex.ru

Константинова Елена Сергеевна, старший преподаватель, Красноярский государственный медицинский университет имени профессора В.Ф. Войно-Ясенеикого elena15k@mail.ru

Фомина Елена Геннадьевна, старший преподаватель, Красноярский государственный медицинский университет имени профессора В.Ф. Войно-Ясенечкого

fomina_lat@rambler.ru

Аннотация: Данная статья посвящена рассмотрению нравственных идеалов учащихся медицинских специальностей КрасГМУ. Идея служения больному утрачивает свою значимость: студенты не готовы вести себя подобно врачам гуманистам прошлого и служить больным повсеместно.

Ключевые слова: медицинское образования, гуманизм, нравственное воспитание, студенты медицинских специальностей.

лов современного студента-медика при выборе профессии.

Материалом послужили анкеты студентов первого курса Красноярского государственного медицинского университета, проанализированные на основе количественного метода.

В анкетировании приняли участие 57 респондентов. Учащимся было предложено анонимно ответить на несколько вопросов, среди которых были следующие: 1) Кто из врачей прошлого является для Вас примером? 2) Готовы ли Вы поехать работать врачом в отдалённый населённый пункт?

Вопрос о том, кто из врачей является примером вызвал затруднения примерно у трети студентов: 18 человек дать ответ не смогли. Одна треть студентов (19 чел.) назвали имена медиков, которые являются для них примером. Среди выдающихся врачей прошлого студенты 
называли имена В.Ф. Войно-Ясенецкого (14 чел), Н.И. Пирогова (1 чел.), писателя и врача А.П. Чехова (1 чел.), Дж. Москатти (1 чел.), Гиппократа (1 чел.), Авиценны (1 чел.). Среди современников фигурировали имена выдающихся медиков и учёных (6 чел.): Н.П. Бехтеровой, Л. Бокерии, Н.М. Амосова, М.И. Попова, выпускника КрасГМУ Х.Ж. Баиева, индийского нейрохирурга П. Каланити. Отметим, что ряд студентов (7 чел.) назвали своих родителей, родственников, знакомых практикующих врачей. Следует также отметить, некоторые студенты в качестве идеалов называли героя телесериала доктора Хауса (2 чел.). Два человека заявили, что сами станут идеалом врача.

Итоги опроса свидетельствуют, что нравственные ориентиры размыты у трети студентов, поскольку они не могли сказать что-либо о своем нравственном идеале. У двух третей какой-либо идеал присутствует, но тут встает вопрос, а какого рода этот идеал?

С точки зрения потребностей всего российского общества в целом, необходимо, чтобы были врачи, готовые работать и служить больным, проживающим в сельской местности, в районах с тяжелыми климатическими условиями, в условиях бытовой необустроенности, в глуши и на окраине страны. В дореволюционной России находилось немало врачей, готовых служить и в сельской местности, и далеких необустроенных уголках Российской Империи. Антон Павлович Чехов заболел туберкулезом, работая врачом на о. Сахалин. Будущий святой Русской Православной Церкви Валентин Феликсович Войно-Ясенецкий начинал свою врачебную карьеру как сельский врач. Другой будущий русский святой, сын придворного врача, Евгений Сергеевич Боткин, сменил более чем обустроенный повседневный быт столичного СанктПетербурга на землянки Манчжурии, чтобы оказывать помощь рядовым солдатам русско-японской войны $[5,6,10,11]$.

Но результаты анкетирования проведенного среди первокурсников КРасГМУ показывают, что студенты не готовы вести себя подобно врачам гуманистам прошлого и служить больным везде где это потребуется.

Половина студентов (50\%) ответила на данный вопрос решительным «нет». Вторая половина студентов высказала согласие поехать в отдалённый населенный пункт только при наличии хороших условий работы и жизни, хорошей зарплаты, непродолжительности срока. Десять человек (18\% от общего числа респондентов) согласны поехать в свою родную деревню.

Данная ситуация является следствием событий 1990x гг.: смена ценностных ориентаций в отечественной педагогике, критика понятий «патриотизм», «коллективизм», везде где это потребуется «долг», «дисциплина», введение новых понятий, таких как «толерантность», «успешность», «карьерный рост» и др. Мы согласны с мнением С.В. Подзоровой [7], что именно критика понятий «долг», «дисциплина», «коллективизм» лежит в основе того, что будущие врачи абсолютно не видят никакого своего долга в том, чтобы служить Родине и служить наиболее обездоленным и ущемленным в своих правах людям [7, с.52] . Если В.Ф. Войно-Ясенецкий, работая в сельской местности в царское время, был представителем того движения, которое в учебниках по школьной истории называется народничеством, когда состоявшие в профессиональном качестве люди ехали в деревню работать земскими врачами, учителями, чиновниками, то сегодняшние первокурсники в полной мере являют собой следствие деградации духовных основ русской жизни.

Без наличия глубокого нравственного стержня будущие врачи будут, скорее всего, вести себя именно так, как описывают ситуацию взаимоотношений сегодняшних врачей и пациентов Церпицкая О.Л., Мануковский В.А. и Ковалевская Н.В. [12], которые пишут об обезличенном отношении врача к пациенту, о том, что общение подразумевает личностный фактор, а на деле «перед врачом находится зачастую уже не человек как таковой, а абстрактный «образ болезни», и знать, кто за ним стоит в ряде медицинских специализаций вообще не обязательно» $[12$, с. 5]. Подобный подход, естественно, трансформирует медицину из служения (или социально значимой работы и науки) в сферу услуг (на что мы уже обратили внимание при оценке лингвистических изменений).

Приходится констатировать, что все, изложенное выше, привело к ситуации, в которой врач практически равен медицинскому оборудованию, призванному обеспечивать выполнение услуги, а медицинская практика теперь относится к сфере потребления пациентом.

В то же время история отечественной медицины свидетельствует о глубоких традициях гуманизма в отношении между врачом и пациентом. Исповедуя принципы доброты, милосердия, сострадания, отечественная медицинская школа дала множество примеров врачейгуманистов: Н.И. Пирогова, Е.С. Боткина, В.М. Бехтерева, В.Ф. Войно-Ясенецкого и многих других.

Отрадно отметить, что, отвечая на вопрос об идеале врача, студентами наиболее часто (25\%) называлось имя выдающегося врача В.Ф. Войно-Ясенецкого, вся подвижническая жизнь которого стала примером беззаветного служения людям, примером нравственности и гуманизма [2]. Святитель Лука, отбывал ссылку в Красноярском крае и в г. Красноярске, где ни на день не прекращал исполнять свой долг врача. Имя В.Ф. Войно-Ясенецкого носит Красноярский государственный медицинский университет. Историческая память красноярцев, сохра- 
нение в системе вуза традиций, связанных с именем Святителя Луки способствуют тому, что учащиеся КрасГМУ знакомы с историей жизни и профессиональным наследием выдающегося врача-гуманиста.

Деятельность Святителя Луки наряду с другими православными врачами, развили и обогатили идеи медицинской этики, развив проблемы доверия между врачом и пациентом, доминирования интересов пациента, вопросы профессиональной этики, связь с православной христианской традицией милосердия [9, с. 92 - 97].

Именно нравственность и гуманизм должны быть основой подготовки молодых специалистов в области здравоохранения. Формирование этих двух составляющих профессии врача должно происходить не только в рамках клинических дисциплин, но также на занятиях гуманитарного цикла.

Представление о профессиональной этике, гуманизме и нравственной составляющей профессии врача формируется у будущих врачей уже с первых дней обучения в медицинском вузе. Этому должны способствовать все предметы учебного цикла, в том числе гуманитарные дисциплины. Задача преподавателя - подтолкнуть студентов к размышлениям о том, каким должен быть настоящий врач, каким должно быть его отношение к людям.

Знакомство с биографией, жизненным и профессиональным опытом врачей-подвижников должно стимулировать интерес студентов к проблеме доброты и милосердия, способствовать формированию нравственного идеала врача. По мнению профессора И.В. Силуяновой, настоящим врачом может быть только тот, кто чувствует чужую боль, умеет сопереживать, готов посвятить свою жизнь служению людям [8].

В заключении отметим, что, несмотря на плотный учебный план и насыщенность программы медицинского вуза, вопросы нравственности всегда должны оставаться в центре внимания преподавателей, служить основой для формирования взглядов молодого специалиста и его профессионального становления. Обращение к гуманитарной традиции мировой и отечественной медицины, опыту врачей-подвижников дает к этому все возможности.

\section{ЛИТЕРАТУРА}

1. Агеев А.Н. Духовно-нравственное воспитание как основа саморегуляции зрелой личности // Психология и педагогика: методика и проблемы 2011. № $19-2$ c.47-51

2. Архиепископ Лука (Войно-Ясенецкий). Я полюбил страдание. Автобиография. Акафист святителю Луке, исповеднику, Архиепископу Крымскому. М.: ОБРАЗ, 2011. $-128 \mathrm{C}$.

3. Гальцова Е.С. Проблемы духовно-нравственного воспитания личности в современной России // Вестник ПСТГУ IV: Педагогика. Психология 2014. Вып. 1 (32). C. 25-32

4. ущина А.В. Воспитание добродетелей как педагогическая проблема // Поволжский педагогический вестник. 2018. Том 6, № 3(20) с.40-46

5. Евгений Боткин: Лейб-медик Евгений Боткин прославлен на Архиерейском Соборе 2016 года [Электронный ресурс]. / Редакция портала «Православие и мир». URL: http://www.pravmir.ru/ya-dal-tsaryu-chestnoe-slovo-ostavatsya-pri-nem-do-teh-por-poka-on-zhiv/ (дата обращения 05.01.2019 г.)

6. Кудрявцева-Вельманс 0.А. Лебединая песня доктора Е.С. Боткина // Медицинская этика. Ежеквартальный научно-методический журнал. 2016. №1. [Электронный ресурс]. URL: http://medical-ethics.ru/periodical/4/14.pdf (дата обращения 05.01.2019 г.)

7. Подзорова С.В. К вопросу о сущности понятия «нравственность // Современная наука № 2 (5) 2011 c.51-55]

8. Силуянова И.В. Шесть принципов врачебной этики доктора Боткина [Электронный ресурс]. URL: https://www.pravmir.ru/vrachebnaya-etika-mertvyi-lidela-bez-veryi1/ (дата обращения 05.01.2019 г.)

9. Силуянова И.В. Биомедицинская этика. Учебник и практикум. М.: Юрайт. 2017. 311 с.

10. Терлецкий 0.В. Святой врач страстотерпец Евгений Боткин [Электронный ресурc]. URL:terletsky.ru/sv_strastoterpets_vrach_evgeniy_botkin. html (дата обращения 05.01.2019 г.)

11. Царский лейб-медик. Жизнь и подвиг Евгения Боткина / Сост. О. Т. Ковалевская. СПб.: Царское село», 2017. 538 с.

12. Церпицкая 0.Л., Мануковский В.А., Ковалевская Н.В. Новые тенденции во взаимоотношениях врача и пациента // Скорая медицинская помощь. 2016Т: 17 № 1 C. $4-8$

( ) Тюрина Татьяна Валерьевна (tyurina12@mail.ru), Хлякин Олег Сергеевич (khlyakin@yandex.ru), Константинова Елена Сергеевна (elena15k@mail.ru), Фомина Елена Геннадьевна (fomina_lat@rambler.ru). 